\title{
CALCINOSIS
}

\section{HISTOLOGICAL AND CHEMICAL ANALYSIS}

\author{
BY \\ G. LOEWI AND J. DORLING \\ M.R.C. Rheumatism Research Unit, Canadian Red Cross Memorial Hospital, Taplow, Bucks.
}

This paper is concerned with the histological appearances and the chemical analysis of calcinotic tissue. The object was to discover which tissue constituents become calcified in this condition and what modification of the tissue is associated with the calcification process.

\section{Materials AND Methods}

Tissue was obtained from seven cases of calcinosis at autopsy or biopsy. Of these (clinical data given by Ansell, Hamilton and Bywaters, 1964), four showed calcinosis associated with frank dermatomyositis; another two showed collodion patches as the only evidence of dermatomyositis; the last case showed only an isolated lesion of calcinosis post mortem. Part of each specimen was fixed in formalin for paraffin sections, while a thin slice was rapidly frozen in a mixture of solid carbon dioxide and alcohol for sectioning at $-20^{\circ} \mathrm{C}$. In other cases, thin slices of fresh tissue were hand-cut for incubation in enzyme, solutions, as described below, and subsequently fixed and sectioned.

Decalcification of sections or slices of tissue was usually carried out in a 10 per cent. solution of E.D.T.A., adjusted to $\mathrm{pH} 7 \cdot 0$, but some sections were decalcified in acid.

Sections were stained by haematoxylin and eosin, by the Picro-Mallory technique, Heidenhain's azan, and von Kossa's or the chloranilic acid method for calcium salts. Other stains used were orcein, the periodic acid-Schiff (PAS) method, Feulgen, and azure A. Some sections were stained for tyrosine by the method of Lillie (1957).

Enzymes.-Proteolytic and mucolytic fractions of elastase were kindly supplied by Dr. D. A. Hall of the School of Medicine, Leeds (Hall, 1955). The two fractions were used in combination at a ratio of five parts of the proteolytic to one of the mucolytic fraction. The enzyme was dissolved at a concentration of $1 \mathrm{mg}$. per $\mathrm{ml}$. in $\mathrm{M} / 15$ phosphate buffer, $\mathrm{pH} 8 \cdot 4$. Collagenase $\mathrm{ABC}$ Form II was obtained from Agricultural Biologicals Corporation. It was dissolved at $1 \mathrm{mg}$. per $\mathrm{ml}$. in a solution of $0.1 \mathrm{M} \mathrm{NaCl}, 0.1 \mathrm{M} \mathrm{CaCl}_{2}$, and $0.05 \mathrm{M}$ borate at pH 7.0. Crystalline trypsin (Armour Labora- tories, Inc.) was used at a concentration of $1 \mathrm{mg}$. per $\mathrm{ml}$. in $\mathrm{M} / 15$ phosphate buffer at $\mathrm{pH} \mathbf{8} \cdot \mathbf{0}$.

Sections and slices of tissue were left in contact with enzyme or buffer control solution for periods of several hours, at $37^{\circ} \mathrm{C}$., in a moist chamber.

Chemical Procedures.-Finely divided tissue was dried in a desiccator. Fat extraction was carried out with petroleum ether (b.p. $40-60^{\circ}$ ). Acid hydrolysis was carried out in closed ampoules at $100^{\circ} \mathrm{C}$. Nitrogen was determined by micro-Kjeldahl, hexosamine by a modification of the method of Elson and Morgan (1933), hydroxyproline by the method of Neuman and Logan (1950), and tyrosine by the method of Udenfriend and Cooper (1952). Calcium and phosphorus were estimated by standard methods described by King (1951). Twodimensional chromatograms for amino acids were kindly carried out by Dr. R. Consden.

\section{Results and Discussion}

\section{Morphology and Staining Characteristics}

The characteristic appearance of the calcinotic lesion is shown in Figs 1, 2, and 3 (opposite). The spaces, irregular in outline and located amongst connective tissue, were filled by amorphous calcified material. In the material described in this paper we have only seen one instance in which the appearances suggested calcification of muscle fibre remnants (Fig. 4, overleaf). Cellularity of the tissue immediately surrounding the foci of calcinosis was variable. In some of our cases, the dense connective tissue was almost acellular while in others in the vicinity of foci of calcification there were considerable numbers of cells having the appearance of fibroblasts. Inflammatory cells, such as polymorphs, lymphocytes, or plasma cells, were only very rarely seen in this situation. At some distance, however, from the calcific foci, accumulations of inflammatory round cells could quite frequently be found, often surrounding small blood vessels. 

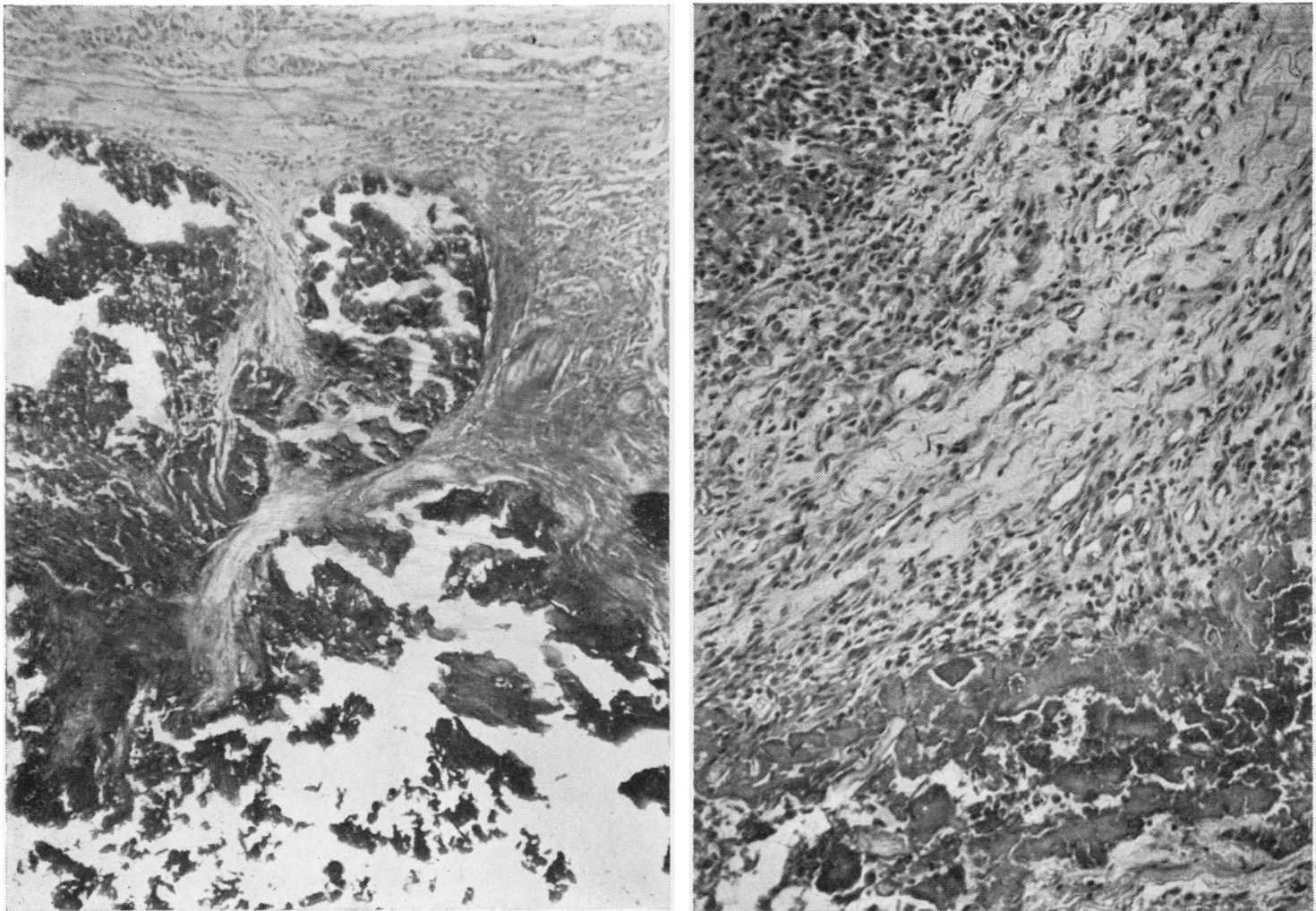

Fig. 1.-Subcutaneous lesion of calcinosis. Biopsy from male aged

Fig. 2.- Subcutaneous calcinotic lesion (biopsy) from male aged 7 17 suffering from dermatomyositis. The calcified material is in the midst of relatively acellular connective tissue. Haematoxylin and with a collodion patch as the only evidence of dermatomyositis. Section shows many fibroblasts along edge of calcified tissue. Haematoxylin and eosin. $\times 85$.

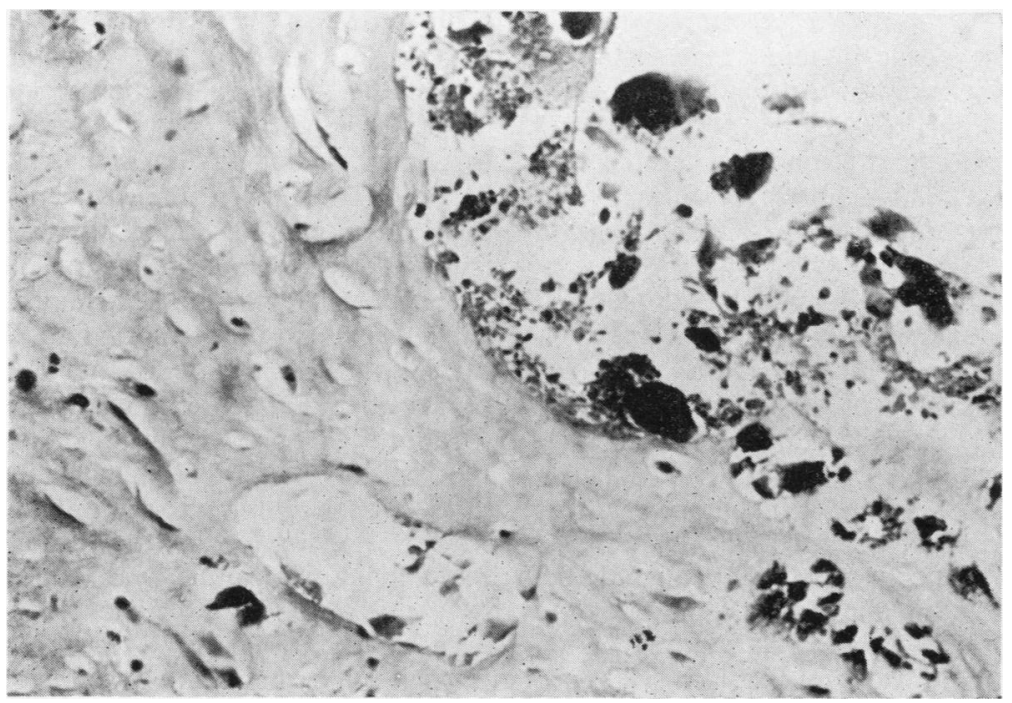

Fig. 3. - Calcinotic lesion from deep intermuscular connective tissue of the leg. Biopsy from same patient as in Fig. 1. Connective tissue shows very few cells. Haematoxylin and eosin. $\times 200$. 


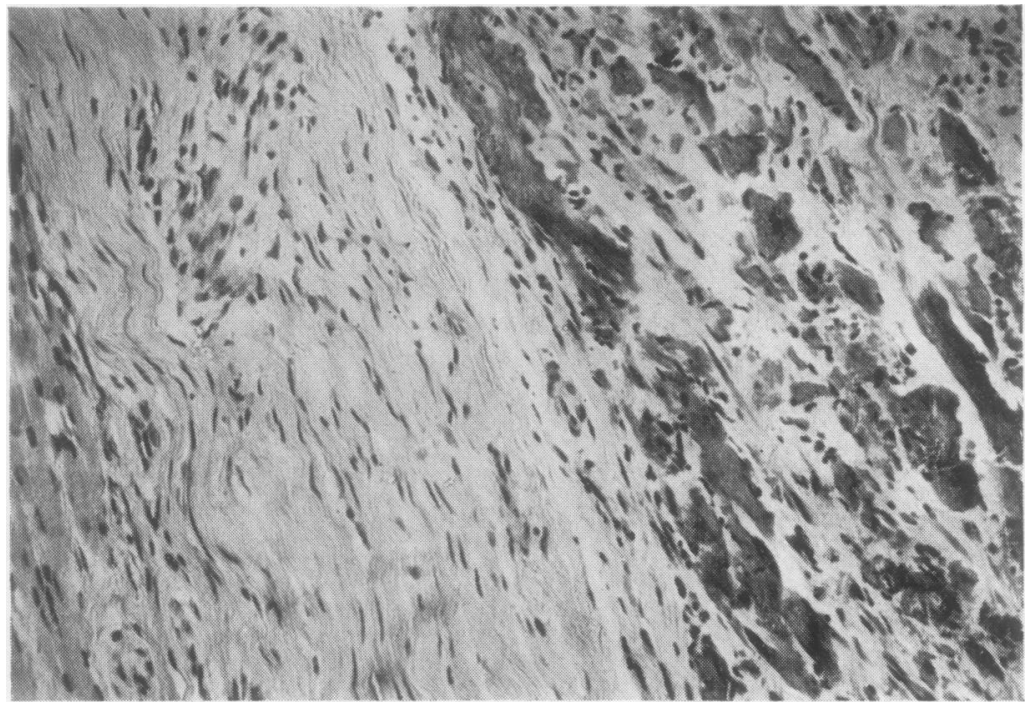

Fig. 4.-Muscle and intermuscular connective tissue from same patient as in Fig. 2. Right-hand side of picture shows calcified bundles, probably of muscular origin. Haematoxylin and eosin. $\times 150$.

In the vicinity of some calcinotic foci, there were fibrils showing the morphological characteristics of elastic fibres, although they were frequently more fragmented and bulky than the normal elastic fibres of connective tissue. These fibres could be stained by both the orcein and von Kossa methods (Figs 5 and 6, opposite).

While it must be borne in mind that abnormal collagen fibres may take the orcein stain (Loewi, Glynn, and Dorling, 1960), their situation and morphological appearances strongly suggested that these were calcified elastic fibres: calcification of these fibres may represent an early stage in the lesion of calcinosis.

Staining by the Picro-Mallory technique showed blue calcinotic material with the surrounding connective tissue similarly stained blue, with some red fibrils. Azan gave a similar blue colour to calcinotic foci. Both methods showed small red-stained fragments among the predominantly blue matrix. Collagen fibres are stained blue by these techniques, but as there were no morphologically distinct fibres in the calcinotic matrix, it was not possible to conclude the collagenous nature of the material. Staining by the PAS reaction produced intense red staining of the calcinotic matrix. Prior decalcification did not affect these staining results but, owing to the acidic conditions used with the Picro-Mallory, Azan, and PAS methods, some decalcification must have occurred during staining. Orcein stained undecalcified calcinotic matrix brown with an intensity similar to that shown by elastin. After decalcification, some areas retained this staining property, but others were coloured a light blue similar to that of surrounding collagen. With Azure A there was slight patchy metachromasia of calcinotic matrix, with orthochromasia of surrounding connective tissue. The Feulgen reaction served to demonstrate a small number of nuclei at the periphery of calcinotic areas, but failed to stain the bulk of the material. The reaction for tyrosine was similar in intensity in the calcinotic and in the surrounding connective tissue. Staining for fat by the oil-Red-O method showed a small amount of stained material irregularly distributed in calcinotic foci. Before decalcification, the Gomori technique showed degrees of toning of the calcinotic matrix as seen with collagen without showing actual fibres. After decalcification, much of this staining became less intense or changed to grey, but some small argyrophil fibrils and clumps were found amongst the amorphous material. Staining by chloranilic acid (Fig. 7, opposite) and by von Kossa's method confirmed the presence of calcium salts.

The results of staining were therefore inconclusive with regard to the nature of the calcified matrix, but they suggested that the material was not predominantly polysaccharide or fat, but more probably protein. 


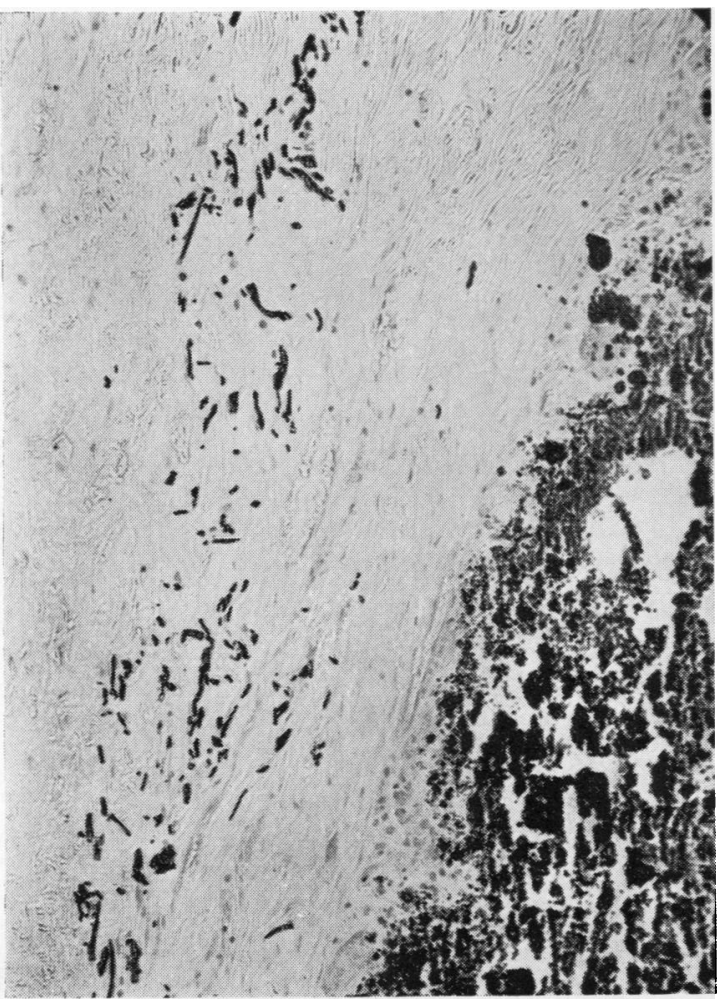

Fig. 5.-Edge of subcutaneous calcinotic lesion. Post mortem specimen from female aged 14 suffering from dermatomyositis. Fibrils stained by von Kossa's method for calcium salts. The calcinotic areas and fibrils are blackened. $\times 200$.

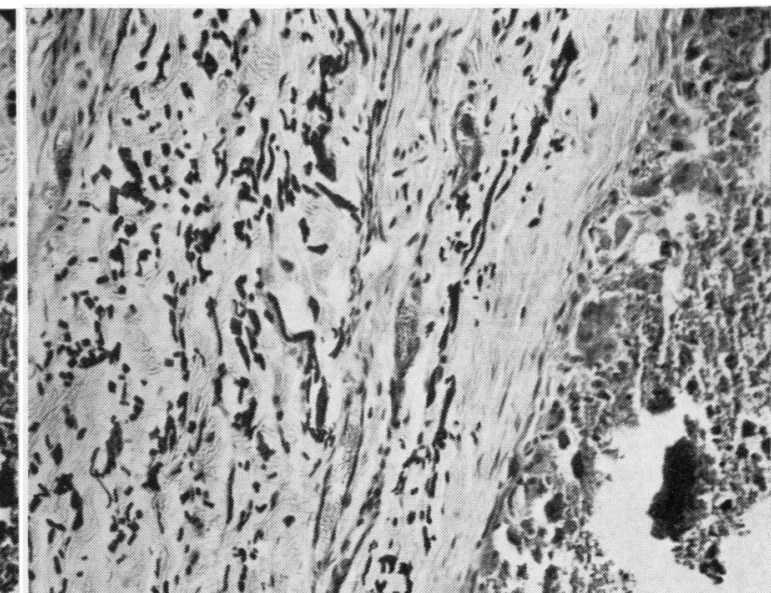

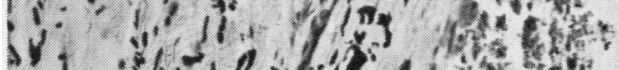

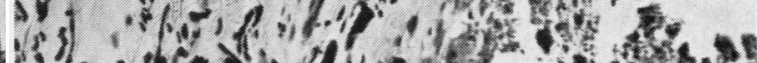

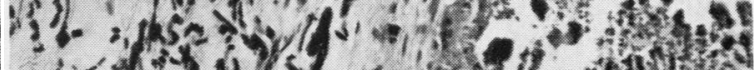
ki..

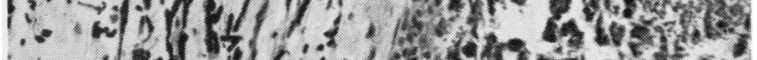

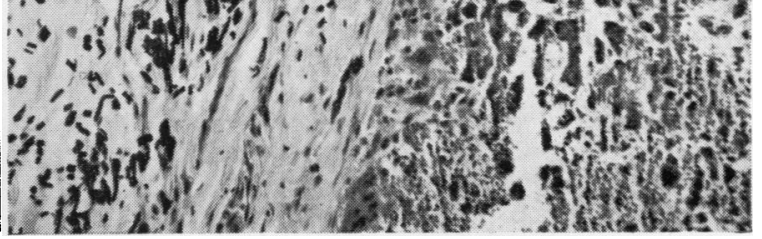

Fig. 6.-As Fig. 5, but stained by orcein. $\times 200$.

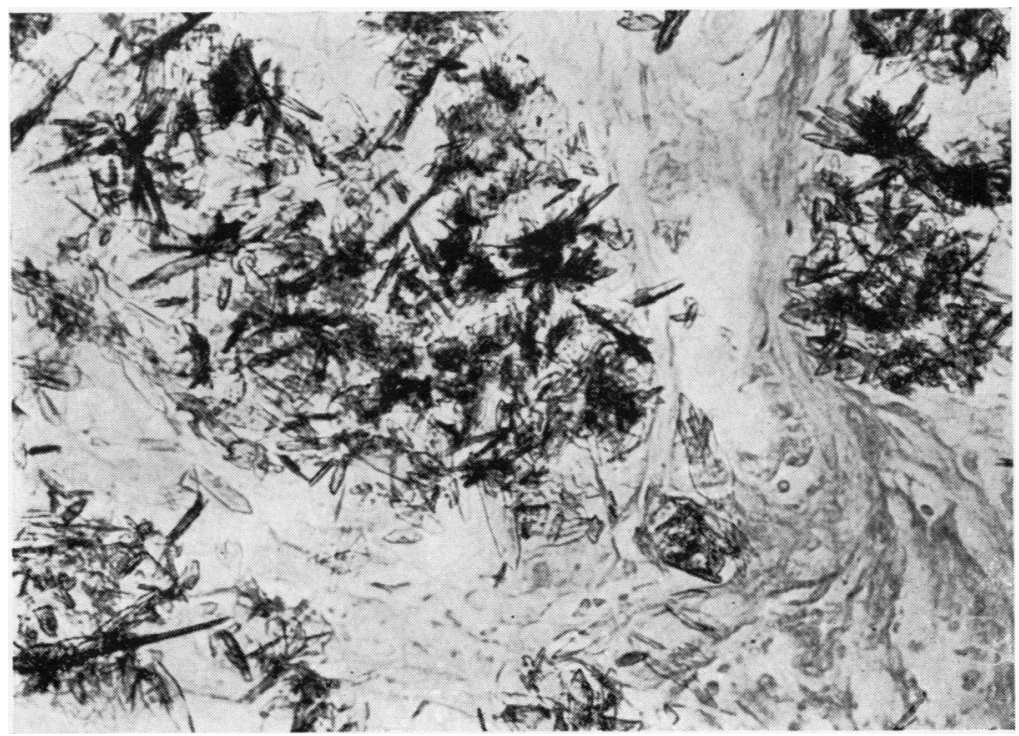

Fig. 7.-Calcinotic lesion. Same patient as in Fig. 1. Calcium shown by chloranilic acid method. $\times 200$. 
Enzymatic Digestion.-Lesions from three patients with calcinosis were studied, giving similar results. One had dermatomyositis, another showed collodion patches as the only sign of dermatomyositis, and the third had only an isolated patch of calcinosis.

When collagenase, trypsin, or elastase was used on fresh calcinotic tissue, calcified material was not broken down, and the surrounding tissue was attacked in the expected way, i.e. collagen was broken down by collagenase and elastic fibres by elastase; trypsin affected staining and caused blurring of structures, but left the calcified tissue intact (Fig. 8). On the other hand, when incubation with enzyme was preceded by decalcification by E.D.T.A., an enzymatic effect on the matrix was seen. Both elastase and trypsin caused partial or, in some cases, complete removal of the material after such decalcification (Figs 9 and 10), unlike their effects on native collagen. Holes were left in the tissue in places where the calcinotic material had been. The surrounding tissue framework was left behind, although its staining characteristics and structure were affected by the treatment. Incubation in buffer alone did not remove the matrix. Collagenase, on the other hand, did not cause removal of decalcified matrix, although the collagen of the surrounding tissue was attacked and much of it disappeared (Fig. 11, opposite). Treatment with E.D.T.A. only or incubation with buffers after decalcification did not lead to removal of residual matrix, but only to some diminution in intensity of staining.

Two conclusions can be drawn from these results:

(1) Proteolytic enzymes could only attack the tissue after decalcification. This is in agreement with the work of Fawns and Landells (1953).

(2) Digestion by trypsin and elastase indicates the protein nature of the matrix.

Elastase, in spite of its name, attacks not only elastin, but also other proteins, (Fullmer and Lillie, 1958; Bagdy, 1959). Trypsin has a wide specificity for proteins, but does not digest native collagen. When collagen has been treated by acetylation,

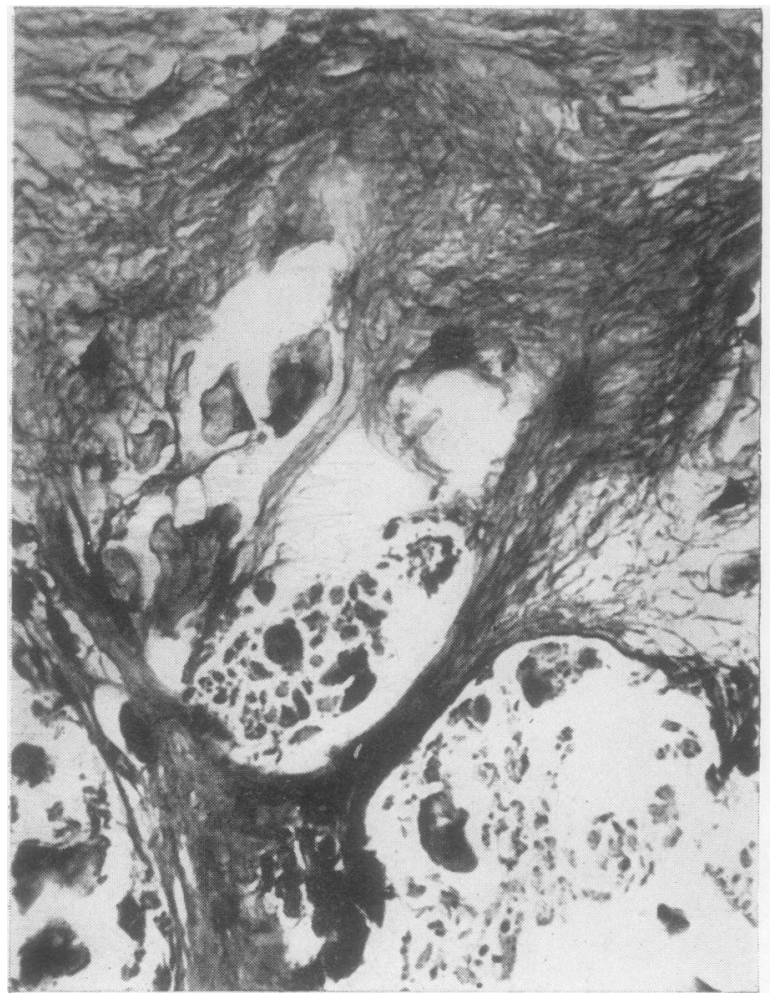

Fig. 8.-Calcinotic tissue, obtained at biopsy from a female aged 14 with dermatomyositis, exposed to trypsin without prior decalcification. Calcinotic material has withstood the treatment. Picro-Mallory stain. $\times 200$

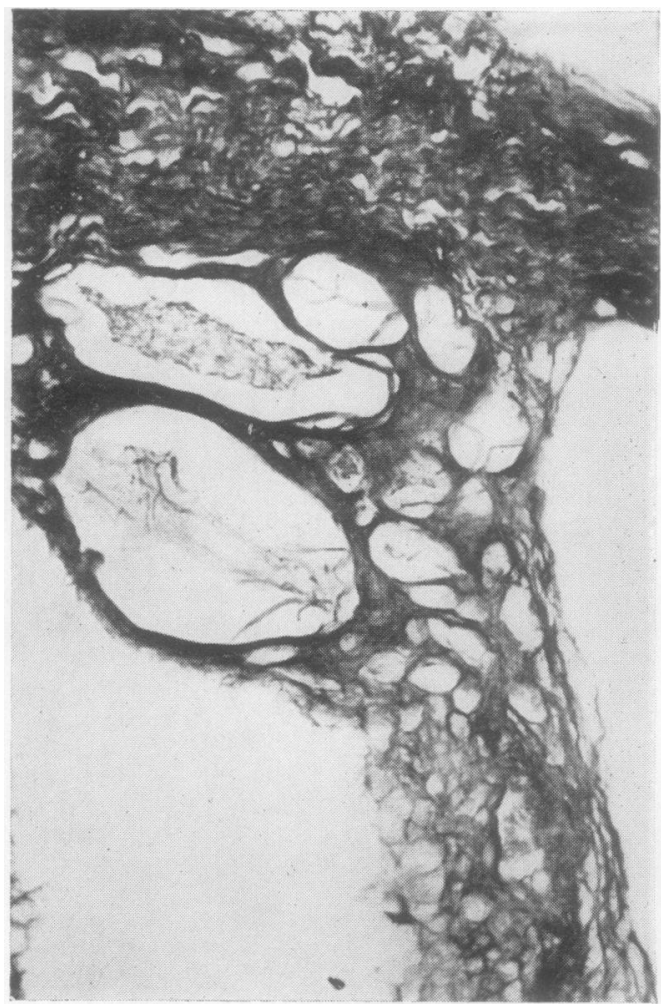

Fig. 9.-Calcinotic lesion, same source as in Fig. 8, decalcified by E.D.T.A. and then exposed to trypsin. The calcinotic matrix has largely disappeared. Picro-Mallory stain. $\times 200$. 


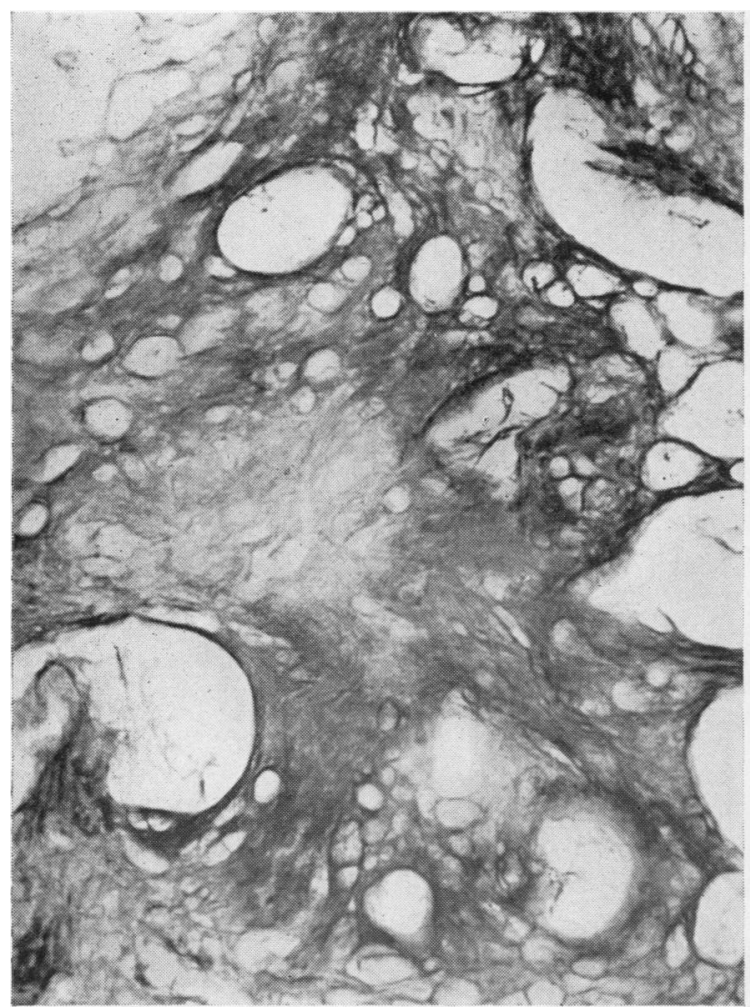

Fig. 10.-Calcinotic lesion, same source as in Fig. 8, decalcified by E.D.T.A. and then exposed to elastase. The calcinotic matrix has been removed. Picro-Mallory stain. $\times 200$.

salicylates, or heat, however, it becomes susceptible to elastase and trypsin (Loewi and others, 1960). The resistance of calcinotic matrix to collagenase may imply either that the material is not predominantly collagen or that collagen has been changed in such a way that it has lost susceptibility to collagenase (Loewi and others, 1960). That calcification per se does not cause collagen to change its susceptibilities to these three enzymes was shown by treating bone slices similarly. The bony matrix was not attacked without prior decalcification, but after decalcification the matrix was digested by collagenase (Fig. 12, overleaf), but left intact by trypsin or elastase (Fig. 13, overleaf).

Chemical Analysis. - The analysis which is detailed here, was performed on material obtained from a patient who had an isolated patch of subcutaneous calcinosis and died from an unrelated cause. The calcified core of the tissue was dissected, free as far as possible from the surrounding connective tissue and the two collections of tissue so obtained analysed separately. The histological appearances of this lesion and results of enzymatic

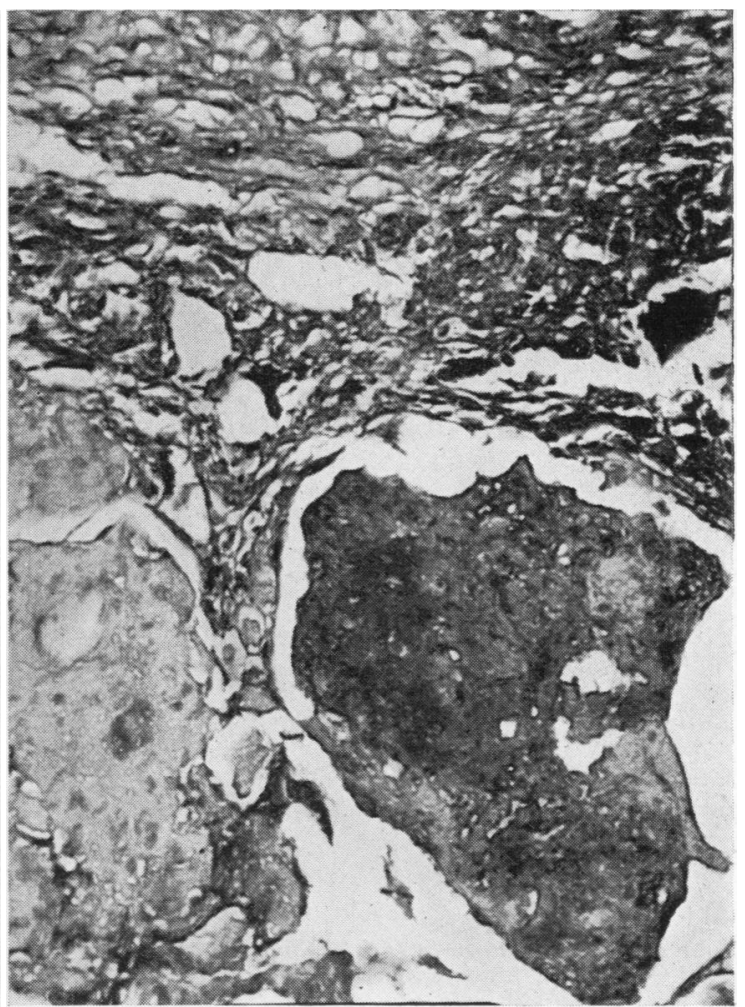

Fig. 11.-Calcinotic lesion, same source as in Fig. 8, decalcified by E.D.T.A. and treated with collagenase. The calcinotic matrix has remained. Picro-Mallory stain. $\times 200$.

digestion were as described above. The results of analysis are shown in Table I, together with some data from a second case of calcinosis, in which the lesions had been associated with dermatomyositis.

TABLE I

ANALYSIS OF SUBCUTANEOUS LESIONS OF CALCINOSIS

\begin{tabular}{|c|c|c|c|c|c|c|}
\hline \multicolumn{4}{|c|}{ Case No. } & \multicolumn{2}{|c|}{1} & 2 \\
\hline \multicolumn{4}{|c|}{ Tissue } & Calcinotic & $\begin{array}{c}\text { Surrounding } \\
\text { Connective }\end{array}$ & Calcinotic \\
\hline Water & . & $\cdots$ & $\cdots$ & 45 & 84 & 50 \\
\hline Protein* & . & . & $\ldots$ & $7 \cdot 7$ & $8 \cdot 7$ & \\
\hline Calcium & . & .. & $\ldots$ & $15 \cdot 4$ & $0 \cdot 4$ & $13 \cdot 0$ \\
\hline Fat & $\cdots$ & . & .. & $2 \cdot 2$ & $3 \cdot 0$ & $1 \cdot 8$ \\
\hline Hexosam & & .. & $\cdots$ & 0.2 & $0 \cdot 1$ & \\
\hline $\begin{array}{l}\text { OH-prolir } \\
\text { cent. of }\end{array}$ & Tot & $\begin{array}{l}\text { s per } \\
\left.v_{2}\right)\end{array}$ & $\cdots$ & $7 \cdot 35$ & $5 \cdot 25$ & \\
\hline $\begin{array}{r}\text { Tyrosine } \\
\text { cent. }\end{array}$ & 12 & & $\cdots$ & 0.97 & 0.94 & \\
\hline
\end{tabular}

Weights expressed as $\mathrm{mg} . / 100 \mathrm{mg}$. wet tissue

* Obtained by multiplying figure for total $\mathrm{N}_{2}$ by $6 \cdot 25$.

The figures show a decreased moisture content as well as somewhat less protein in the calcinotic as 


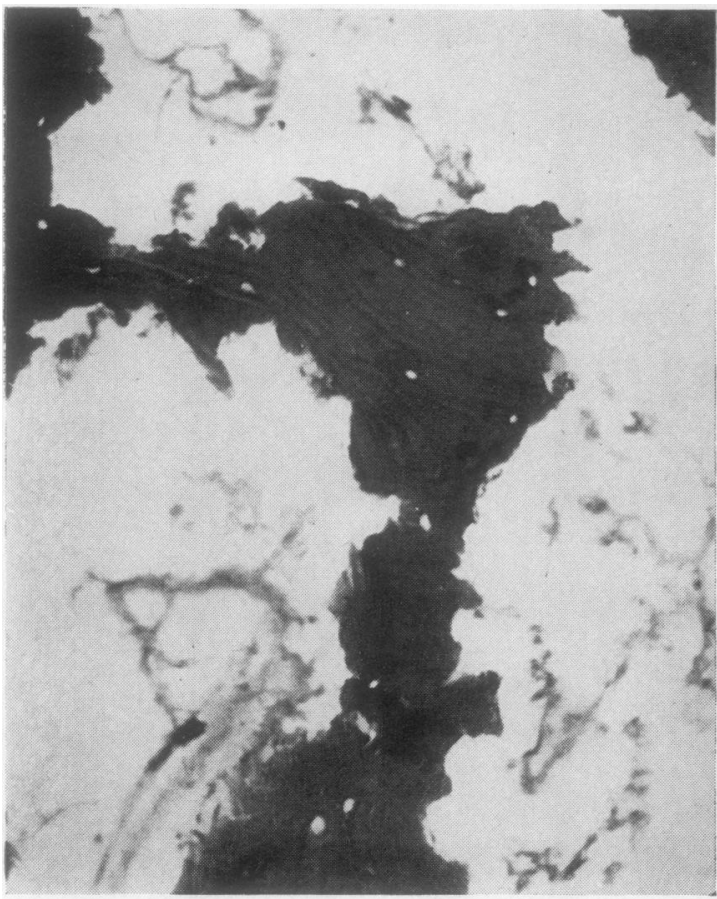

Fig. 12.- Section of bone decalcified by E.D.T.A. and then treated with collagenase. The matrix has been extensively digested. Haematoxylin and eosin. $\times 200$.

opposed to the surrounding connective tissue. Calcium, when calculated as hydroxy-apatite, the form in which it is probably present, accounts for nearly 40 per cent. of the weight of the tissue, bringing the total of five constituents in Table I (Case 1) to 100 per cent. approximately. The proportion of protein present as collagen is greater in the calcinotic material than in the surrounding tissue; that present as tyrosine is similar in the two samples, indicating a similar content of plasma

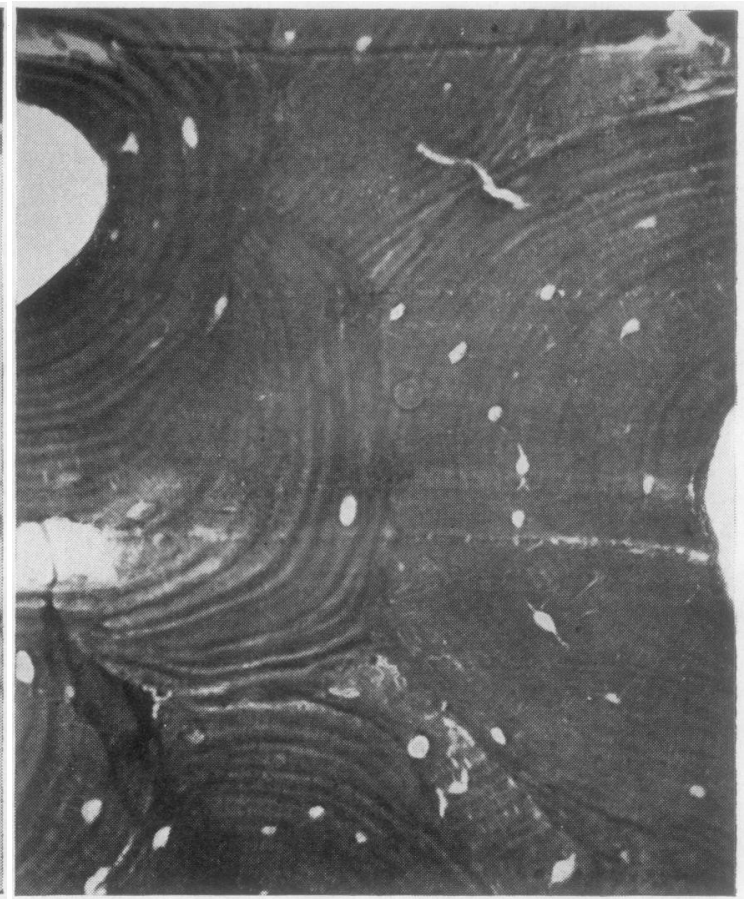

Fig. 13.-Section of bone decalcified by E.D.T.A. and treated with trypsin. The bony matrix remains. Orcein and van Gieson. $\times 200$.

proteins. Tissue hexosamine is contributed from various sources, but the figures suggest that there is no excessive amount of polysaccharide in the tissue.

Since it is possible to distinguish collagen from non-collagenous protein by its solubility in water at $100^{\circ} \mathrm{C}$. under pressure (Neuman and Logan, 1950), samples of tissue were so treated. The results shown in Table II confirm that most of the protein present in the calcinotic focus is a form of collagen. Amino-acid chromatograms showed a pattern con-

TABLE II

RESULTS OF AUTOCLAVING TISSUE AT $100^{\circ}$ C. FOR 48 HRS

\begin{tabular}{|c|c|c|c|c|c|c|c|c|c|}
\hline \multirow[t]{2}{*}{ Tissue .. } & \multirow[t]{2}{*}{.. } & \multirow[t]{2}{*}{.. } & \multirow[t]{2}{*}{.. } & \multirow[t]{2}{*}{. } & . & \multicolumn{2}{|l|}{ Calcinotic } & \multicolumn{2}{|c|}{ Surrounding Connective } \\
\hline & & & & & & Supernatant & Residue & Supernatant & Residue \\
\hline Total $\mathbf{N}_{2}$ & . & . & . & . & & $2 \cdot 4$ & 0.5 & $6 \cdot 7$ & $2 \cdot 1$ \\
\hline \multicolumn{5}{|c|}{$\mathrm{OH}$-proline $\mathrm{N}_{2}$ (as per cent. of total $\mathrm{N}_{2}$ ) } & . & $7 \cdot 6$ & $1 \cdot 7$ & $6 \cdot 2$ & $2 \cdot 3$ \\
\hline $\mathbf{C a}$ & . & . & . & . & - & 0.25 & $25 \cdot 9$ & 0.53 & $\overline{3} \cdot \overline{0}$ \\
\hline . & . & . & . & . & . & 0.03 & $4 \cdot 2$ & 0.04 & $1 \cdot 3$ \\
\hline \multicolumn{3}{|c|}{$\mathrm{NH}_{2}$-acid Chromatogram } & . & . & . & Consistent with collagen & Not done & Consistent with collagen & $\begin{array}{c}\text { Consistent with elastin }+ \\
\text { residual collagen }\end{array}$ \\
\hline
\end{tabular}


sistent with collagen; in twoothercases, lessextensively studied, the chromatograms showed some hydroxyproline, thus providing evidence for collagen.

The results of chemical analysis therefore suggest that the calcified matrix in calcinosis might be altered collagen. Calcification might take place in collagen which has undergone change and also on some elastic fibres. The failure of digestion by collagenase may be compared with the findings of Loewi and others (1960), that the connective tissue of senile elastosis was refractory to the action of collagenase and that experimental acetylation of collagen similarly led to a collagenase-resistant material, thus showing that collagen may undergo changes which alter its enzyme susceptibility. That collagen may be the focus for calcification has been shown for normal bone and dentine by the work of Solomons and Irving (1958) and for collagen implants by Mergenhagen, Martin, Rizzo, Wright, and Scott (1960). In an accompanying communication, Davis and colleagues (paper in preparation) show that apatite crystals can be seen by electron microscopy to be associated with collagen in calcinosis.

\section{Summary}

Tissue from cases of calcinosis, with and without dermatomyositis, obtained at biopsy or post mortem, has been examined. It was noted that the calcified masses appeared in connective tissue, often in the neighbourhood of muscle. In some cases the tissue surrounding these masses contained small calcified fibrils giving staining reactions of elastin. Most lesions showed little cellular reaction. In an effort to elucidate the nature of the tissue undergoing calcification, histochemical, histo-enzymatic, and analytical chemical procedures were used. Trypsin and elastase were effective in digesting the calcinotic matrix only after decalcification. Collagenase was without effect. Analysis showed a high hydroxyproline content, from which it must be deduced that the protein of the calcinotic matrix consists largely of collagen, although no fibres could be seen by light microscopy. The questions why such collagen undergoes calcification and why it is not digested by collagenase have not yet been elucidated.

\section{REFERENCES}

Ansell, B. M., Hamilton, E. B. D., and Bywaters, E. G. L. (1964). Ann. rheum. Dis., in preparation.

Bagdy, D. (1959). Experientia, 15, 122.

Elson, L. A., and Morgan, W. T. J. (1933). Biochem. $J ., 27,1824$

Fawns, H. T., and Landells, J. W. (1953). Ann. rheum. Dis., 12, 105.
Fullmer, H. M., and Lillie, R. D. (1958). J. Histochem. Cytochem., 6, 425.

Hall, D. A. (1955). Biochem. J., 59, 459.

King, E. J. (1951). "Micro-analysis in Medical Biochemistry", 2nd ed., pp. 64, 84. Churchill, London.

Lillie, R. D. (1957). J. Histochem. Cytochem., 5, 528.

Loewi, G., Glynn, L. E., and Dorling, J. (1960). J. Path. Bact., 80, 1.

Mergenhagen, S. E., Martin, G. R., Rizzo, A. A., Wright, D. N., and Scott, D. B. (1960). Biochim. Biophys. Acta, 43, 563.

Neuman, R. E., and Logan, M. A. (1950). J. biol. Chem., 186, 549.

Solomons, C. C., and Irving, J. T. (1958). Biochem. J., 68,499 .

Udenfriend, S., and Cooper, J. R. (1952). J. biol. Chem., 196, 227.

Calcinose - analyse chimique et histologique

RÉSUMÉ

On a examiné des tissus des cas de calcinose, avec ou sans dermatomyosite, obtenus à la biopsie ou à l'autopsie. On a noté que les masses calcifiées apparaissaient dans le tissu conjonctif, souvent au voisinage du muscle. Dans quelques cas le tissu autour de ces masses contenait de petites fibrilles calcifiées prenant les mêmes colorants que l'élastine. La plupart des lésions accusaient peu de réaction cellulaire. Pour élucider la nature du tissu subissant la calcification, on s'est servi de procédés histochimiques, histo-enzymatiques et de chimie analytique. La trypsine et l'élastase digéraient la matrice calcinotique seulement après la décalcification. La collagénase n'exerçait aucun effet. L'analyse montra un taux élevé d'hydroxyproline; on en déduit que la protéine de la matrice calcinotique consiste surtout en collagène, bien qu'on ne puisse pas observer de fibres au microscope lumineux. Il n'est pas encore clair pourquoi ce collagène se calcifie et pourquoi il n'est pas digéré par la collagénase.

\section{Calcinosis-análisis químico e histológico}

\section{SUMARIO}

Se examinaron tejidos, obtenidos de biopsias o autopsias de casos de calcinosis con o sin dermatomiositis. Se notó que las masas calcificadas aparecían en el tejido conectivo, a menudo en la vecindad del músculo. En algunos casos el tejido alrededor de estas masas contenía pequeñas fibrillas calcificadas que acusaban las mismas reacciones de coloración que la elastina. La mayoría de estas lesiones mostraban pocas reacciones celulares. Para aclarar la naturaleza del tejido que se calcifica, se emplearon procedimientos histoquímicos, histo-enzimáticos y quimio-análíticos. La tripsina y la elastasa digerían la matriz calcinótica solamente después de la descalcificación. La colagenasa no ejercía efecto alguno. El análisis evidenció altas cifras de hidroxiprolina, de lo cual se deduce que la proteina de la matriz calcinótica consiste en su mayor parte de colágeno, aunque no se pueda observar fibras con el microscopio luminoso. No se sabe todavía porqué este colágeno se calcifica y porqué la colagenasa no le digiere. 